\title{
JUKMAS
}

Jurnal Untuk Masyarakat Sehat (JUKMAS)

e-ISSN : 2715-7687

Vol. 4, No. 1 April 2020

P-ISSN : 2715-8748

\section{Analisis Faktor Yang Berhubungan Dengan Kesediaan Ibu Hamil Melakukan Tes Hiv Di Wilayah Kerja Upt Puskesmas Cimanggis Depok Tahun 2019}

\author{
Eni Ernawati, Herman Sudiman, Sri Widodo \\ Public Health Science Study Program, Post Graduate Faculty \\ University Of Respati Indonesia \\ Email : erni_ernawati784@gmail.com
}

\begin{abstract}
ABSTRAK
HIV/AIDS merupakan masalah kesehatan di seluruh dunia termasuk Indonesia. Data pada tahun 2018 jumlah ibu hamil yang melakukan tes HIV di Indonesia sebanyak 5.291.143 orang dari jumlah total 761.373 ibu hamil (13,38\%) dan yang terinfeksi HIV positif tercatat 2.955 orang, sementara yang sudah mendapatkan terapi ARV baru sekitar 893 ibu hamil, setiap tahunnya terus mengalami peningkatan Dalam hal ini tes HIV selama kehamilan merupakan salah satu upaya untuk mencegah penularan HIV dari ibu ke anak. Penelitian ini menganalisa faktor yang berhubungan dengan kesediaan ibu hamil untuk melakukan tes HIV. Penelitian ini adalah deskriptif analitik dengan pendekatan kuantitatif dan rancangan penelitian cros-sectional dengan variabel yang diamati adalah variabel independen dan variabel dependen. Sampel penelitian adalah 124 ibu hamil. Teknik pengambilan sampel purposive sampling dengan kriteria inklusi dan eksklusi yang sudah ditetapkan, serta wawancara menggunakan kuesioner terstruktur. Populasi data menggunakan analisa univariat, bivariat dengan uji chi-square dan analisis multivariat dengan regresi logistik berganda. Hasil penelitian menunjukkan bahwa sebagian besar responden $(66,9 \%)$ bersedia tes HIV. Faktor yang ditemukan berhubungan dengan kesediaan tes HIV oleh ibu hamil adalah faktor variabel pengetahuan terhadap HIV/AIDS $(O R=4,790)$, pekerjaan ibu hamil $(O R=1,795)$, faktor jumlah ANC $(O R=1,332)$, faktor usia kehamilan(OR=1,323), dan faktor dukungan suami $(O R=0,538)$. Sedangkan usia, pendidikan, sikap, paritas, dukungan sesama ibu hamil, dukungan petugas kesehatan dan akses pelayanan tidak berhubungan secara signifikan dengan kesediaan ibu hamil melakukan tes HIV. Kesimpulan dari penelitian ini bahwa pengetahuan merupakan variabel yang paling dominan dari faktor yang berhubungan signifikan dengan kesediaan ibu hamil melakukan tes HIV diantara variabel pekerjaan, jumlah ANC, usia kehamilan dan dukungan suami atau keluarga.
\end{abstract}

Kata Kunci : kesediaan tes HIV, ibu hamil, Cimanggis, Depok

Daftar Pustaka : 34 (2009-2018)

\section{ABSTRACT}

HIV/AIDS is a health problem throughout the world, including Indonesia. Data in 2018 pregnant women taking HIV in Indonesia as 5.291.143 people there were 761.373 pregnant women $(13,38 \%)$ and 2.955 infected with HIV, have received ARV therapy 893 pregnant women and increased every year.. HIV testing during pregnancy is one way to prevent the transmission of HIV from mother to child. This study aims to determine the 
reasons behind the acceptance of pregnant women in undergoing HIV testing and the factors associated with the client willingness. This study was quantitative methods study design was cross sectional with independent variable and dependent variable, a large sample of 124 expectant mothers. Sampling use purposive sampling with predetermined inclusion dan exclusion criteria. Data were collected by interviews using a structured questionnaire. Data Population use univariate data analysis, bivariate chi-square test and multivariate analysis with logistic regression was used to assess findings. The results showed that the majority of respondents $(66,9 \%)$ would be willing to test for HIV. Factors associated with the acceptance of HIV testing by expectant mothers were knowledge of HIV/AIDS $(O R=4,790)$, employment status $(O R=1,795)$, frequency of ANC $(O R=1,332)$, gestational age $(O R=1,323)$ and husband support $(O R=0,538)$. Factors of age, education, attitude, parity, fellow pregnant mothers support, health workers support and service access were not significantly associated with acceptance of HIV testing by expectant mothers. The conclusions of the study is factors associated with the acceptance of HIV testing by expectant mothers were knowledge of HIV/AIDS, employment status, frequency of ANC, gestational age and husband support.

Keywords : willingness of HIV testing, expectant mothers, cimanggis, depok

References : 34 (2009-2018)

\section{LATAR BELAKANG}

Penyebaran virus HIV sudah masuk dalam tahap feminisasi (perempuan yang terinfeksi makin tinggi). Hal ini dapat dibuktikan dari penelitian, bahwa di Asia tahun 2008 diperkirakan ada 50 juta perempuan berisiko terinfeksi HIV dari pasangan intimnya. Salah satu faktor penyebab terjadinya feminisasi AIDS adalah ketidakadilan gender yang masih kuat di masyarakat (KPAN, 2010). Laporan Epidemi HIV Global UNAIDS 2013, diperkirakan 36,9 juta orang hidup dengan HIV di seluruh dunia dan lebih dari 1,8 juta orang diantaranya adalah anak anak dibawah 15 tahun dengan infeksi HIV, angka ini menunjukkan penurunan sebanyak $35 \%$ dari jumlah infeksi baru tahun 2010 ada 270 ribu menjadi 180 ribu pada tahun 2017 (UNAIDS, 2013). Proporsi perempuan yang hidup dengan HIV tetap stabil, hampir $50 \%$ dari total global. Sekitar 15 juta orang dewasa yang hidup dengan HIV adalah perempuan. Di Sub-Sahara Afrika tahun 2011, perempuan merupakan 58 dari orang dewasa yang hidup dengan HIV (WHO, 2014).

Berdasarkan data Kementerian Kesehatan pada Tahun 2015 jumlah perempuan yang terinfeksi HIV sebanyak 12.573.meningkat pada tahun 2016 menjadi 15.151 dan menurun di tahun 2017 menjadi 3.511 (Ditjen PP \& PL Kemenkes R1,2017). Saat ini, Ibu rumah tangga menempati urutan ke tiga terbesar orang dengan HIV AIDS (ODHA). Faktor risiko penular terbanyak heteroseksual $(69,9 \%)$, homoseksual 
(5.7\%), penasun $(9,1 \%)$, penularan melalui perinatal (2,9\%). Tes HIV pada ibu hamil hanya sekitar 13,38 \% (761.373 orang) dari jumlah total ibu hamil di Indonesia sebanyak 5.291 .143 orang, dari jumlah yang menjalani tes tersebut yang diketahui positif HIV tercatat 2.955 orang, sementara yang mendapat terapi ARV dalam upaya menekan jumlah virus (VL) lebih sedikit lagi yaitu 893 ibu hamil (Kemenkes RI, 2018).

Kenaikan angka temuan HIV positif berdasarkan kunjungan ibu hamil ke PITC dari 2013 - 20018 menambah risiko anak-anak juga tertular dari orang tuanya. Untuk mencegah penularan HIV dari ibu ke anak, Pemerintah Indonesia mencanangkan program layanan Pencegahan Penularan HIV dari Ibu ke Anak (PPIA) sejak tahun 2004.

Jumlah ibu hamil dengan HIV positif yang dilaporkan dari tahun 2013 hingga 2017 mengalami kenaikan tiap tahunnya, jumlah infeksi HIV tertinggi yaitu di DKI Jakarta (2.896), kemudian peringkat kedua Papua (2.128), ketiga Jawa Barat sebanyak (1.690), keempat Jawa Tengah (1.627), kelima Jawa Timur (1.246) ; Data KPAN, 2018. Provinsi Jawa Barat menempati urutan ketiga di Indonesia, dari 94.209 ibu hamil yang berkunjung dilayanan kesehatan dan bersedia di tes HIV ditemukan 229 ibu hamil terinfeksi HIV positif. (Sumber data layanan VCT Provinsi Jawa Barat tahun 2018).

Jumlah Kumulatif kasus HIV \& AIDS di Kota Depok tahun 2000- 2017 sebanyak 965 Kasus, dengan perincian 36 AIDS dan 88 ibu hamil HIV positif dari 929 orang yang terinfeksi HIV. sedangkan pada tahun 2018 terdapat 15.190 orang yang melakukan tes diantaranya 9.509 ibu hamil, didapatkan jumlah ibu hamil HIV positif sebanyak sembilan orang (Dinkes Kota Depok, Profil kesehatan, 2019).

Dari sisi provider untuk menangani HIV/ AIDS, fasilitas layanan kesehatan Kota Depok pada tahun 2018 yang dapat melakukan layanan VCT dan PITC, terdiri dari 22 Puskesmas dari 35 Puskesmas yang ada dan 2 Rumah Sakit. Layanan kesehatan yang juga berfungsi sebagai layanan Care, Support and Treatment (CST). dan menjadi rujukan bagi layanan sekitarnya. Pada tahun 2016, pemeriksaan HIV pada ibu hamil hanya dilakukan di Puskesmas yang mempunyai SDM yang sudah terlatih \& memiliki layanan VCT dan PITC saja, namun mulai tahun 2017 pemeriksaan HIV pada ibu hamil menjadi bagian layanan ANC terpadu yang dilakukan oleh Puskesmas dan sebagian BPM. Cakupan pemeriksaan HIV pada ibu hamil belum dapat menjangkau seluruh ibu hamil hal ini disebabkan belum 
semua Puskemas memiliki fasilitas penunjang skrining HIV dan petugas terlatih, pelaksanaan skrining HIV pada ibu hamil dibidan praktek mandiri dan layanan kesehatan swasta lainnya belum ada serta adanya penolakan dari ibu hamil untuk dilakukan skrining turut mempengaruhi capaian skrining ini.

UPT Puskesmas Cimanggis berdiri sejak Tahun 1968, merupakan puskesmas 24 jam yang dilengkapi dengan fasilitas layanan Poned, rawat inap, laboratorium dan merupakan salah satu puskesmas tertua di Kota Depok dan percontohan nasional yang ditetapkan oleh Kementerian Kesehatan RI HK.01.07/MENKES/636/2018, serta memiliki pelayanan ANC dan program PMTCT dengan sistem pelayanan dan pencatatan Sistem Informasi HIV AIDS (SIHA) yang baik. Berdasarkan data tahun 2017 jumlah kunjungan ibu hamil yang bersedia di tes HIV sebanyak 1.917 orang dari 2.246, dari pemeriksaan tersebut ada 4 ibu hamil yang terinfeksi HIV positif. dan pada tahun 2018 yang bersedia di tes HIV ada 3.862 orang $(71,6 \%)$, sedangkan 1.534 orang $(28,43 \%)$ tidak bersedia di tes. Dari pemeriksaan ibu hamil selama tahun 2017-2018 ditemukan 7 ibu hamil dengan HIV positif yang tersebar di wilayah kerja kecamatan yang ada di Kota Depok ,kasus ini, sering terjadi pada
ANC di K4, sehingga sulit untuk tata laksana ARV pada ibu hamil \& bayi yang akan dilahirkan. Alasan kesediaan melakukan tes HIV adalah karena memahami penjelasan petugas kesehatan dan ada kekhawatiran penularan HIV. Pemeriksaan

HIV pada ibu hamil merupakan peluang yang baik dalam upaya mencegah penularan HIV dari ibu ke bayi. Namun dari hasil wawancara awal kepada beberapa ibu hamil, diketahui bahwa berbagai faktor dapat mempengaruhi kesediaan ibu hamil terhadap tes HIV. Ketidakbersediaan ibu hamil untuk tes HIV ada yang merasa tidak mungkin tertular HIV, ada yang malu ke klinik PITC, ada yang takut dengan hasil tesnya, ada yang kesibukan bekerja dan ada yang tidak mendapat persetujuan dari suami.

\section{METODE PENELITIAN}

Jenis penelitian ini adalah penelitian deskriftif analitik dengan pendekatan kuantitatif. Rancangan penelitian ini menggunakan rancangan cross sectional, variabel yang diamati adalah Variabel Independen seperti usia ibu hamil, pekerjaan, pendidikan, jumlah kunjungan ANC, sikap, paritas, usia kehamilan, pengetahuan tentang HIV dan PPIA, keterjangkauan akses layanan, 
dukungan suami dan keluarga, dukungan petugas pelayanan kesehatan dan dukungan teman sedangkan Variabel Dependennya adalah kesediaan ibu hamil untuk melakukan tes HIV.

Teknik pengambilan sampel adalah purposive sampling. Pengertian menurut Notoatmodjo (2010) teknik pengambilan sampel yang berdasarkan atas suatu pertimbangan tertentu seperti sifat sifat populasi ataupun ciri- ciri yang sudah diketahui sebelumnya, Teknik ini menjadi pilihan peneliti karena lebih mudah dalam mengambil kasus atau responden dengan cara menetapkan ciri-ciri khusus sesuai dengan kriteria inklusi dan eksklusi yang sudah ditetapkan dalam penelitian. Peneliti mengambil sampel dari setiap kunjungan ibu hamil yang melakukan ANC di UPT Puskesmas Cimanggis, lokasi penelitian mulai 15 April 2019 sampai dengan 15 Mei 2019 yang memenuhi kriteria inklusi sampai dipenuhi 124 sampel. Peneliti memiliki asumsi bahwa semua ibu hamil yang melakukan pemeriksaan ANC Wajib tes HIV karena kesediaan melakukan tes sudah merupakan kebijakan Nasional sesuai dengan PERMENKES No 4 Tahun 2019 tentang SPM kesehatan ibu Hamil wajib tes HIV $100 \%$.

Penelitian dilakukan setelah mendapat rekomendasi dari Komisi Etik Penelitian Kesehatan Program Pascasarjana
Program Studi IImu Kesehatan Masyarakat, Universitas Respati Indonesia dan dinyatakan layak berdasarkan Surat Keterangan Nomor : 014/SK.KEPK/UNR/IV/19 tanggal 13 April 2019 dan telah melakukan penelitian dan pengambilan data dari Dinas Kesehatan Kota Depok dengan Surat Keterangan Nomor : 070/3296-Umum, tanggal 11 Juli 2019 dan Surat telah melaksanakan pengambilan data penelitian dari UPT Puskesmas Cimanggis dengan Nomor 440/256-CMG, tanggal 10 Juli 2019.

\section{HASIL PENELITIAN DAN PEMBAHASAN}

Tabel 1 Kesediaan ibu hamil tes HIV di UPT Puskesmas Cimanggis Kota Depok

\begin{tabular}{lc}
\hline Kesediaan Tes HIV & $\mathrm{n}(\%)$ \\
\hline Ya & $83(66,9)$ \\
Tidak & $41(33,1)$ \\
Jumlah & $124(100)$ \\
\hline
\end{tabular}

Ibu hamil yang bersedia melakukan tes hiv yaitu 83 orang $(66.9 \%)$ sedangkan yang tidak bersedia atau menolak tes hiv ada 41 orang $(33.1 \%)$

Tabel 2 Penelitian Responden di UPT Puskesmas Cimanggis Kota Depok

\begin{tabular}{lcc}
\hline Responden & $\mathrm{n}=124$ & $\%$ \\
\hline Usia & & \\
$<20$ Tahun & 6 & 4,8 \\
20-30 & 58 & 46,8 \\
$\geq 31$ Tahun & 60 & 48.4 \\
\hline
\end{tabular}


Berdasarkan Tabel 2 menunjukkan bahwa Usia Ibu Hamil masih ada yang dibawah 20 tahun sekitar 6 orang $(4,8 \%)$,usia $20-30$ tahun 58 orang $(46,8 \%)$ dan usia tua lebih sama dengan 31 tahun, ada 60 orang $(48,4 \%)$.

Tabel 3 Pendidikan ibu hamil dan suami

Pendidikan Ibu Hamil masih ada yang SD/ sederajat sebanyak 11 orang (8.9\%), SMP /sederajat 26 orang $(21,0 \%)$ .SMA /sederajat 65 orang $(52,4 \%)$ dan PT S-1 ada 22 orang (17.7\%) sedangkan pendidikan suami tidak jauh berbeda, yaitu SD/sederajat 13 orang $(10,5 \%)$, SMP/sederajat 14 orang $(11,3 \%)$,SMA /sederajat 78 orang (62.9\%) sedangkan yang tingkat pendidikannya tinggi sekitar 19 orang $(15,3 \%)$

Tabel 4 Pekerjaan ibu hamil

\begin{tabular}{lcc}
\hline Karakteristik Responden & $\mathrm{n}=124$ & $\%$ \\
\hline Pekerjaan ibu & & \\
Ibu Rumah Tangga & 84 & 67,7 \\
Swasta & 23 & 18,5 \\
PNS & 1 & 0,8 \\
& & \\
Guru & 5 & 4,0 \\
$\quad$ Buruh / Kuli cuci & 11 & 8,9 \\
Pekerjaan Suami & & \\
$\quad$ Tidak bekerja & 2 & 1,6 \\
Swasta & 79 & 63,7 \\
& & \\
PNS & 4 & 3,2 \\
Guru & 3 & 2,4 \\
Buruh Pabrik /kasar & 36 & 29,0 \\
\hline
\end{tabular}

Pekerjaan Ibu Hamil paling banyak adalah Ibu Rumah Tangga yaitu 84 orang $(67,7 \%)$ dan Ibu Hamil yang bekerja swasta 23 orang $(18,5 \%)$, guru ada 5 orang (4,0\%), buruh /kuli cuci ada 11 orang $(8,9 \%)$ sedangkan suami yang paling banyak bekerja

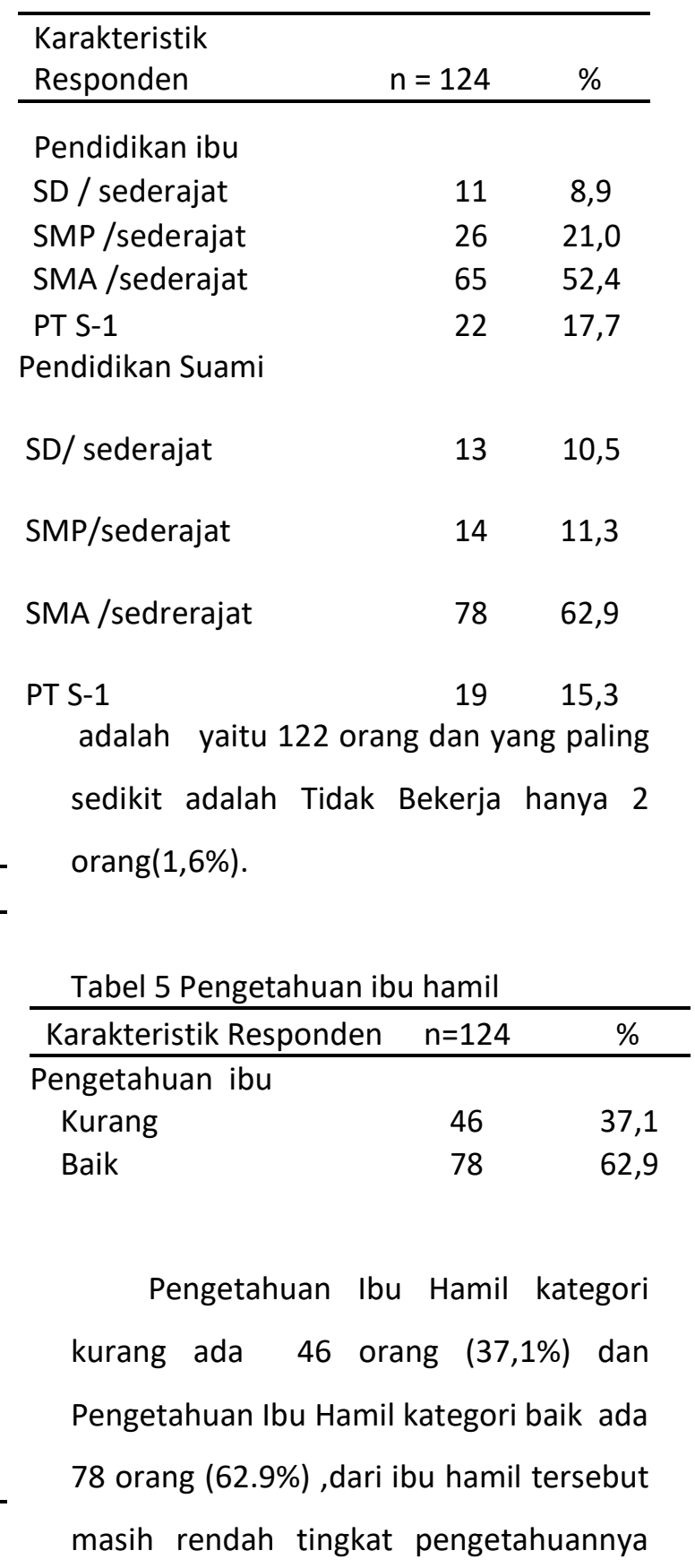


tentang manfaat tes hiv, dan yang mengetahui hanya 38 Orang $(3,92 \%)$.

Sikap ibu hamil hasilnya sama dengan pengetahuan ibu hamil, yaitu sikap ibu hamil yang positif/ mendukung ada 78 orang $(62,9 \%)$ dan Sikap Ibu Hamil yang negatif/ menolak ada 46 orang $(37,1 \%)$, dari yang menolak tersebut masih banyak yang menganggap tes HIV tidak penting $(7,065 \%)$, tidak memberikan manfaat $(7,91 \%)$ dan belum mengetahui jika ibu hamil mempunyai resiko tertular HIV dari pasangannya $(6,42 \%)$.

Tabel 6 Paritas, Kunjungan ANC dan usia kehamilan.

\begin{tabular}{lrc}
\hline $\begin{array}{l}\text { Karakteristik } \\
\text { Responden }\end{array}$ & $\mathrm{n}=124$ & $\%$ \\
\hline $\begin{array}{l}\text { Paritas } \\
\text { Primigravida }\end{array}$ & 80 & $64,5 \%$ \\
Multigravida & 44 & 35,5 \\
Jumlah kunjungan ANC & & \\
$\quad<3$ kali & 52 & $42,9 \%$ \\
$\quad$ 3 kali & 72 & $58,1 \%$ \\
Usia Kehamilan & & \\
Trimester ke1 dan 2 & 52 & $41,9 \%$ \\
Trimester ke 3 & 72 & $58,1 \%$ \\
& & \\
\hline
\end{tabular}

Paritas yang lebih banyak adalah Paritas primigravida, dengan jumlah anak 1-2 yaitu 80 Orang $(64,5 \%)$ dan Paritas Multigravida dengan jumlah anak 3 atau lebih yaitu 44 Orang $(35,5 \%)$, sedangkan Ibu Hamil yang rutin kontrol ANC lebih banyak, yaitu 72 orang $(58,1 \%)$, dan Ibu
Hamil yang jarang kontrol ANC $<3$ kali dalam periode kehamilan yaitu 52 orang (41,9\%).

Ibu Hamil paling banyak dengan Usia Kehamilan 7-9 bulan/trimester 3 yaitu 72 orang $(58,1 \%)$, dan paling sedikit dengan Usia Kehamilan trimester $1 \& 2$ yaitu 52 orang $(41,9 \%)$.

Tabel 7 Akses layanan kesehatan

\begin{tabular}{lc} 
Karakteristik Responden & $\%$ \\
\hline Akses Layanan kesehatan & \\
Sulit & $33,1 \%$ \\
Mudah ditempuh & $66.9 \%$
\end{tabular}

Dari tabel diatas yang menyatakan kemudahan akses transportasi dengan jarak tempuh $<1 \mathrm{Km}$ dan waktu $<10$ menit ke layanan kesehatan ada 83 orang $(66,9 \%)$, dan Ibu Hamil yang menyatakan akses sulit ada 41 orang $(33,1 \%)$.

Tabel 8 Kesediaan suami di tes, dukungan suami, dukungan teman dan dukungan nakes.

\begin{tabular}{lcc}
\hline $\begin{array}{l}\text { Karakteristik } \\
\text { Responden }\end{array}$ & $\mathrm{n}=124$ & $\%$ \\
\hline $\begin{array}{l}\text { Suami } \\
\begin{array}{l}\text { Bersedia Tes } \\
\text { Tidak bersedia } \\
\text { tes }\end{array}\end{array}$ & 51 & $58,9 \%$ \\
$\begin{array}{l}\text { Dukungan Suami } \\
\text { atau keluarga }\end{array}$ & 73 & $41,1 \%$ \\
$\quad \begin{array}{l}\text { Tidak mendukung } \\
\text { Mendukung }\end{array}$ & 53 & $42,7 \%$ \\
$\begin{array}{l}\text { Dukungan Teman } \\
\quad \text { Tidak mendukung }\end{array}$ & 57 & $57,3 \%$ \\
$\quad \begin{array}{l}\text { Mendukung } \\
\text { Dukungan Nakes }\end{array}$ & 67 & $54 \%$ \\
$\quad \begin{array}{l}\text { Tidak mendukung } \\
\text { Mendukung }\end{array}$ & 36 & $29 \%$ \\
\hline
\end{tabular}

Suami yang bersedia tes yaitu 51 orang $(58,9 \%)$ dan Suami yang 
belum/tidak bersedia tes yaitu 73 orang $(41,1 \%)$, sedangkan Ibu Hamil yang mendapat dukungan suami ada 71 orang $(57,3 \%)$ dan lbu Hamil yang tidak mendapat dukungan suami ada 53 orang $(42,7 \%)$.

Ibu Hamil yang banyak dukungan teman ada 67 orang $(54,0 \%)$ dan Ibu Hamil yang kurang mendapatkan dukungan teman ada 57 orang $(46,0 \%)$, sedangkan dukungan tenaga kesehatan ada 88 orang $(71,0 \%)$ dan yang kurang mendapat dukungan tenaga kesehatan ada 36 orang (29,0\%).

Analisis bivariat menyatakan faktor umur, pendidikan, sikap, paritas, jumlah kunjungan ANC, usia kehamilan, akses layanan kesehatan,, dukungan teman, dan dukungan petugas kesehatan tidak ada hubungan yang signifikan dengan kesediaan tes HIV oleh ibu hamil. Meskipun hasil perhitungan jumlah kunjungan ANC $p$ value $=0,279$ ( $p$ value $>0,25)$, paritas $p$ value $=0,857(p$ value $>$ $0,25)$ dan usia kehamilan $p$ value $=$ $0,278(p$ value $>0,25)$ secara statistik tidak dapat lanjut ke multivariat, namun karena secara substansi variabel kunjungan ANC, paritas dan usia kehamilan sangat penting, maka variabel ini dapat dianalisis multivariat.

Hasil analisis pengetahuan ibu hamil dengan kesediaan tes HIV pada ibu hamil diperoleh bahwa ada sebanyak 59
$(75,6 \%)$ respoden yang memiliki pengetahuan yang baik tentang HIV bersedia untuk tes HIV. Hasil uji statistik chi square diperoleh nilai $p=0,013(\mathrm{OR}=$ 1,310-6,184) maka dapat disimpulkan bahwa pengetahuan ibu hamil ada hubungan yang signifikan antara pengetahuan dengan kesediaan ibu hamil melakukan tes HIV.

Analisis dukungan suami dengan kesediaan ibu hamil tes HIV diperoleh bahwa ada sebanyak $53 \quad(74,6 \%)$ respoden yang mendapat dukungan suami dengan baik bersedia untuk tes HIV. Hasil uji statistik chi square diperoleh nilai $p=0,035$, maka dapat disimpulkan bahwa hampir ada hubungan yang signifikan antara dukungan suami dengan kesediaan tes HIV oleh ibu hamil.

Tabel menunjukkan bahwa pengetahuan ibu hamil tentang HIV memiliki hubungan yang signifikan dengan kesediaan tes HIV oleh ibu hamil, sedangkan dukungan suami hampir memiliki hubungan yang signifikan dengan kesediaan tes HIV oleh ibu hamil. Hasil seleksi Bivariat variabel independen dengan variabel independen, dimana tidak semua variabel menghasilkan $p$ value $<0,25$, namun untuk kunjungan ANC dan paritas walaupun $p$ value nya $>0,25$ tetap dianalisa multivariat, karena secara 
substansi kunjungan ANC, paritas dan usia kehamilan merupakan variabel yang sangat penting yang berhubungan dengan kesediaan ibu hamil melakukan tes HIV.

Tabel 9 Hasil seleksi Bivariat Variabel Independen, $\mathrm{p}$ value dan kandidat multivariat.

\begin{tabular}{|c|c|c|}
\hline $\begin{array}{l}\text { Variabel } \\
\text { independen }\end{array}$ & $p$ value & Keterangan \\
\hline Pekerjaan ibu & 0,168 & $\begin{array}{c}\text { Kandidat } \\
\text { Multivariat }\end{array}$ \\
\hline Pengetahuan & 0,008 & $\begin{array}{l}\text { Kandidat } \\
\text { Multivariat }\end{array}$ \\
\hline $\begin{array}{l}\text { Dukungan } \\
\text { Suami }\end{array}$ & 0,035 & $\begin{array}{l}\text { Kandidat } \\
\text { Multivariat }\end{array}$ \\
\hline Paritas & 0,857 & $\begin{array}{l}\text { Kandidat } \\
\text { Multivariat }\end{array}$ \\
\hline Jumlah ANC & 0,279 & $\begin{array}{c}\text { Kandidat } \\
\text { Multivariat }\end{array}$ \\
\hline $\begin{array}{l}\text { Usia } \\
\text { Kehamilan }\end{array}$ & 0,278 & $\begin{array}{c}\text { Kandidat } \\
\text { Multivariat }\end{array}$ \\
\hline
\end{tabular}

Dari tabel di atas ada yang variabel yang $\mathrm{p}$ value $<0.25$ yaitu : pekerjaan ,pengetahuan ibu hamil, dukungan suami. Sedangkan variabel yang $\mathrm{p}$ value nya $>0,25$ paritas, kunjungan ANC dan usia kehamilan, akan tetapi secara substansi paritas, jumlah ANC, usia kehamilan merupakan faktor penting maka dapat dimasukkan sebagai Kandidat Multivariat.

Tabel 10 Analisis faktor yang berhubungan dengan kesediaan ibu hamil melakukan tes HIV.

\begin{tabular}{|c|c|c|c|c|c|c|}
\hline \multirow[b]{3}{*}{$\begin{array}{c}\text { Tah } \\
\text { ap }\end{array}$} & \multirow[b]{3}{*}{ Variabel } & \multirow{2}{*}{\multicolumn{2}{|c|}{$\mathbf{P}$}} & \multicolumn{2}{|c|}{$95,0 \%$} & \multirow{3}{*}{$\begin{array}{l}\text { Peru } \\
\text { baha } \\
\text { n OR }\end{array}$} \\
\hline & & & & \multicolumn{2}{|c|}{$\mathrm{Cl}$} & \\
\hline & & $\begin{array}{c}\text { Va } \\
\text { lu } \\
\text { e }\end{array}$ & $\begin{array}{l}0 \\
R\end{array}$ & $\begin{array}{l}\text { Lo } \\
\text { we } \\
r\end{array}$ & $\begin{array}{c}\text { Up } \\
\text { pe } \\
\text { r }\end{array}$ & \\
\hline \multirow[b]{4}{*}{ Full } & & .1 & 1. & .80 & \multirow{2}{*}{4.} & \\
\hline & \multirow{3}{*}{ an ibu } & \multirow[t]{3}{*}{68} & 8 & 1 & & \\
\hline & & & 1 & & \multirow{2}{*}{$\begin{array}{c}12 \\
3\end{array}$} & \\
\hline & & & 8 & & & \\
\hline \multirow{20}{*}{$\begin{array}{l}\text { Mo } \\
\text { del }\end{array}$} & 2.Penget & .0 & 4. & .51 & \multirow{4}{*}{$\begin{array}{c}43 \\
.1 \\
34\end{array}$} & \\
\hline & ahuan & \multirow[t]{3}{*}{07} & 7 & \multirow[t]{3}{*}{3} & & \\
\hline & & & 0 & & & \\
\hline & & & 4 & & & \\
\hline & \multirow[t]{3}{*}{ 3.Paritas } & .8 & .9 & .39 & \multirow{3}{*}{$\begin{array}{c}2 . \\
95\end{array}$} & \\
\hline & & \multirow[t]{2}{*}{57} & 1 & 6 & & \\
\hline & & & 1 & & & \\
\hline & 4.Usia & .2 & .1 & .75 & & \\
\hline & kehamila & 79 & .5 & 5 & 2. & \\
\hline & $\mathrm{n}$ & & 1 & & 28 & \\
\hline & & & 8 & & & \\
\hline & 5.Jumlah & .2 & 1. & .59 & & \\
\hline & ANC & 78 & 4 & 2 & $\begin{array}{l}3 . \\
01\end{array}$ & \\
\hline & & & 7 & & 8 & \\
\hline & & & 7 & & & \\
\hline & 6.Dukung & .0 & .5 & .06 & 5. & \\
\hline & an suami & 35 & 5 & 1 & 00 & \\
\hline & & & 1 & & 6 & \\
\hline & 1.Pekerja & .1 & 1. & .79 & & $-1,2$ \\
\hline & an ibu & 68 & 7 & 8 & 03 & $\%$ \\
\hline Mo & & & 9 & & 8 & \\
\hline del & & & 5 & & & \\
\hline ke & 2.Penget & .0 & 4. & .52 & & 1,83 \\
\hline 1 & ahuan & 07 & 7 & 5 & $\begin{array}{c}43 \\
6\end{array}$ & $\%$ \\
\hline & ibu & & 9 & & .0 & \\
\hline & & & 0 & & & \\
\hline & 3. Usia & .1 & 1. & .76 & & 0,68 \\
\hline & kehamila & 65 & 3 & 3 & 2. & $\%$ \\
\hline & $\mathrm{n}$ & & 2 & & 29 & \\
\hline & & & 3 & & & \\
\hline & 4.Jumlah & .2 & 1. & .59 & & - \\
\hline & ANC & 78 & 3 & 0 & 3. & 0,29 \\
\hline & & & 3 & & 6 & $\%$ \\
\hline & & & 2 & & & \\
\hline & 5. & .0 & .5 & .53 & & - \\
\hline & Dukunga & 35 & 3 & 8 & .0 & 2.36 \\
\hline & n suami & & 8 & & 60 & $\%$ \\
\hline & 1.Pekerja & .1 & 1. & .78 & 3. & 3,53 \\
\hline & an ibu & 68 & 7 & 1 & 90 & $\%$ \\
\hline Mo & & & 4 & & 9 & \\
\hline
\end{tabular}




\begin{tabular}{clccccc}
\hline del & & & 7 & & & \\
ke & 2.Penget & .0 & 4. & .52 & & $\mathbf{7 8 \%}$ \\
$\mathbf{2}$ & ahuan & 07 & 8 & 8 & 43 & \\
& ibu & & 2 & & .9 & \\
& & & 0 & & 79 & \\
& 3.Usia & .1 & 1. & .80 & & 2,98 \\
& kehamila & 65 & 3 & 6 & 2. & $\%$ \\
& n & & 8 & & 36 & \\
& & & 0 & & 2 & \\
& 4.Dukung & .0 & .5 & .06 & 4. & 2,04 \\
& an suami & 35 & 4 & 1 & 94 & $\%$ \\
& & & 9 & & 1 & \\
Mo & 1.Penget & .0 & 5. & .55 & 45 & $99 \%$ \\
del & ibuan & 07 & 0 & 4 & .7 & \\
ke & & & 3 & & 72 & \\
3 & 2.Usia & .1 & 1. & .76 & & 4,63 \\
& kehamila & $\mathbf{6 5}$ & 3 & 5 & 2. & $\%$ \\
& n & & 1 & & 26 & \\
& & & 6 & & 3 & \\
& 3.Dukung & .0 & .5 & .05 & 4. & 6,73 \\
& an suami & 35 & 1 & 7 & 60 & $\%$ \\
& & & 2 & & 6 & \\
& 4. Jumlah & .2 & 1. & .56 & 2. & - \\
& ANC & 78 & 2 & 4 & 81 & 99,9 \\
& & & 6 & & 2 & $\%$ \\
& & & 0 & & &
\end{tabular}

ibu 75

$\begin{array}{lcccc}\text { 3.Usia } & .1 & 1 . & .76 & 2 . \\ \text { Kehamila } & 65 & 3 & 3 & 29 \\ \mathrm{n} & & 2 & & 5 \\ & & 3 & & \end{array}$

4.Jumlah $\quad .2 \quad 1 . \quad .59$ ANC $\quad 78 \quad 3 \quad 0 \quad 3$. $\begin{array}{lll}78 & 3 & 0 \\ 3 & 00\end{array}$

$\begin{array}{lllll} & & 2 & & 6 \\ \text { 5.Dukung } & .0 & .5 & .06 & 4 .\end{array}$ $\begin{array}{lllll}\text { an suami } & 35 & 3 & 0 & 85\end{array}$

Dari tabel 10 menunjukkan variabel yang memiliki paritas $p$ value $0,857>$ 0,05 dan lebih besar dari $p$ value yang lainnya. Pemodelan selanjutnya variabel paritas dikeluarkan dari model multivariate, dan apabila didapatkan perubahan nilai OR > 10\% maka variabel dimasukkan kembali kedalam model.Analisis, dilakukan 2 kali tahapan untuk mendapatkan pemodelan akhir dengan mengeluarkan variabel $p$ value terbesar secara berurutan.

Analisis multivariat model terakhir menunjukkan OR pekerjaan : 1,795 (95\%Cl; .798-3.038), berarti ibu hamil yang berstatus ibu rumah tangga berpeluang $1,795 \times$ untuk bersedia tes HIV dibanding ibu hamil yang bekerja.

OR pengetahuan terhadap HIV/AIDS adalah 4,790 $(95 \% \mathrm{Cl}: .525-$ 43.675) berarti ibu hamil yang memiliki pengetahuan yang baik terhadap HIV/AIDS berpeluang $4,790 \times$ untuk bersedia tes HIV dibanding ibu hamil 
yang memiliki pengetahuan yang kurang baik terhadap HIV/AIDS.

Untuk OR usia kehamilan adalah 1,323 $(95 \% \mathrm{Cl}: .763-2.295)$ berarti ibu hamil dengan usia kehamilan trimester ke 3 itu berpeluang 1,323 kali untuk bersedia tes HIV daripada ibu hamil dengan usia kehamilan trimester ke 1 dan 2.

Untuk OR jumlah ANC adalah 1,332 $(95 \% \mathrm{Cl}: .590-3.006)$ berarti ibu hamil yang rajin kunjungan ANC berpeluang 1,332 kali lebih mungkin untuk bersedia tes HIV dari ibu hamil yang jarang kunjungan ANC.

OR dukungan suami adalah 0,538 $(95 \% \mathrm{Cl}: .060-4.850)$ berarti ibu hamil yang mendapat dukungan suami berpeluang 0,538 kali lebih mungkin untuk bersedia tes HIV daripada ibu hamil yang tidak mendapat dukungan suami. Secara tidak langsung bisa dikatakan masih banyak suami yang tidak mengijinkan pasangannya untuk melakukan tes dan mengetahui status HIV nya, sikap suami ini diperkuat dengan data hanya 51 orang yang bersedia tes serta yang mengetahui manfaat tes HIV hanya 43 orang $(4,44 \%)$.

\section{SIMPULAN}

Berdasarkan hasil dari penelitian ini bahwa masih adanya ibu hamil di wilayah kerja UPT Puskesmas Cimanggis yang jarang berkunjungan ANC di trimester pertama, dan masih rendahnya jejaring rujukan dari bidan praktek swasta, RSIA, ke puskesmas setempat, sehingga mempengaruhi capaian skreening yang seharusnya $100 \%$ wajib tes sesuai dengan ketetapan program pemerintah pusat dan daerah.

Faktor yang berhubungan signifikan dengan kesediaan ibu hamil untuk tes HIV adalah pekerjaan (bekerja ataukah tidak bekerja), pengetahuan ibu hamil (baik ataukah kurang pemahaman ibu hamil tentang HIV/AIDS), jumlah kunjungan ANC (rutin ataukah jarang ibu hamil dalam kunjungan ANC) dan usia kehamilan (pada trimester 1 dan 2 atau trimester 3) serta dukungan suami. Faktor yang dominan berhubungan dengan kesediaan melakukan tes HIV adalah pengetahuan, dengan pengetahuan yang baik tentang informasi HIV, manfaat tes, serta mengetahui bahaya dan pencegahan penularan ibu ke anak akan memberikan dampak yang baik terhadap kesehatan dan meningkatkan program PPIA.

Masih ada faktor yang ditemukan tidak berhubungan secara signifikan dengan kesediaan ibu hamil melakukan tes HIV seperti umur, pendidikan ibu hamil, pendidikan suami, sikap, paritas, akses layanan kesehatan, kesediaan 
suami untuk di tes, dukungan teman, dan dukungan tenaga kesehatan.

\section{TERIMA KASIH}

Terima kasih disampaikan kepada Universitas Respati Indonesia Program Pascasarjana Program Studi IImu Kesehatan Masyarakat, khususnya Dosen Pembimbing, Tim Penguji, Temanteman/Opponen, Dinas Kesehatan Kota Depok, UPT Puskesmas Cimanggis.

\section{DAFTAR PUSTAKA}

1. Adeneye, WR Brieger, Adeneye, WR Brieger, MA Mafe, KK Salami, MA Titiloye, 2014. Willingness To Seek HIV Testing And Counceling Among Pregnant Women Attending Antenatal Clinics In Ogun State Nigeria. The Johns Hopkins University, Baltimore, Maryland, University of Ibadan, Nigeria.

2. Alison L. A Alison L. Drake, Anjuli Wagner, Barbra Richardson, Grace John-Stewart, 2014. Incident HIV during Pregnancy and Risk of Mother to Child Transmission : A Systematic Review and Meta Analysis.

3. Bassam H. Rimawi, Lisa Haddad, Martina L. Badell, Rana Chakraborty, 2015. Management of HIV Infection during Pregnancy in the United States; Update
Evidence-Based Recommendations and Future Potential Practices.

4. Dinas Kesehatan Kota Depok, 2019. Profil Kesehatan Kota Depok 2018, Depok.

5. Dinas Kesehatan Kota Depok, 2018. Laporan Bulanan Konseling dan Testing Sukarela (KTS/VCT), Kota Depok.

6. Dwi Mutia Wenny, Yanri Wijayanti, Mohammad Hakimi, 2016. Faktor yang mempengaruhi partisipasi Ibu hamil melakukan skrining HIV di Puskesmas Yogyakarta. Yogyakarta.

7. I Ketut Surya Negara, AAN. Anantasika, Artana Putra,__AAP Wiradnyana,_I Ketut Tunas, 2016, Karakteristik wanita hamil dengan HIV infeksi berikut Pencegahan Ibu ke Anak Program Penularan HIV (PMTCT) di Sanglah rumah sakit umum 2005-2014. Bali Med J, Sanglah.

8. Inka Kartika Ningsih, Sari Hastuti, 2018. Kajian Pencegahan Penularan HIV dari Ibu ke Anak pada Antanatal Care oleh Bidan Praktik Mandiri di Yogyakarta, Jurnal Administrasi Kesehatan Indonesia. Yogyakarta

9. Jurnal IImiah Kebidanan, Vol. 8 No. 2 Edisi Desember 2017, hlm. 67-79 Analisis Perilaku Pencegahan Penularan HIV/AIDS Pada Ibu Hamil 
Di Puskesmas Kalikajar 1 Wonosobo, Wonosobo.

10. Kementerian Kesehatan RI, 2015. Pedoman Manajemen Program Pencegahan Penularan HIV dan Sifilis dari lbu ke Anak, Jakarta.

11. Kemenkes RI, 2018. Profil Kesehatan Indonesia 2017, Pedoman VCT dan PITC, Jakarta.

12. Kemenkes RI, 2018. Direktorat Pencegahan Pengendalian Penyakit Menular Langsung, subddit HIV/AIDS dan PMS, Jakarta

13. Khoiriyah Isni, Zahroh Shaluhiyah, Kusyogo Cahyo, 2017. Pengetahuan Ibu HIV mempengaruhi perilaku pencegahan penularan HIV/AIDS dari Ibu ke Bayi di Propinsi Jawa Tengah. Jurnal Promkes Indonesia. Semarang.

14. Khoiriyah Isni, 2016. Dukungan Keluarga, Dukungan Petugas Kesehatan, Dan Perilaku Ibu Hiv Dalam Pencegahan Penularan Hiv/Aids Ke Bayi, Jurnal Kesmas.

15. M.Husni Ari Santoso, Bambang Wahyono, 2018. Manajemen Program Pelayanan Voluntary Counseling and Testing (VCT), Higeia Jurnal of Public Health Research and Development.

16. Mira Miranti Puspitasari, Purnawan junadi, 2017. Analisis Implementasi Integrasi Layanan PPIA HIV ke
Layanan Antenatal di Kota Depok 2017, Jurnal KKI vol.7 No.2 (2018).

17. Nanik Setiyawati, Niken Meilani, 2015. Determinan of HIV Testing Behavior among Pregnant Women, Jurnal Kesmas Nasional.

18. Notoatmodjo, S. , 2010. Promosi Kesehatan Teori dan Aplikasi, Jakarta, PT. Rineka Cipta

19. Notoatmodjo, S, 2014. Metodologi Penelitian Kesehatan. Edisi Revisi, Jakarta, PT. Rineka Cipta.

20. Peraturan Menteri Kesehatan RI No. 21, 2013. Tentang Penanggulangan HIV dan AIDS

21. Permenkes RI, No. 74, 2014 Tentang Pedoman Pelaksanaan Konseling dan Tes HIV

22. Public Health and Preventive Medicine Archive (PHPMA) 2018, Volume 2, Number 1 : 63-68 E-ISSN ; 2503-2356, Factors related to Acceptance of HIV testing by pregnant Mothers in Health Centres in Denpasar City. Kota Denpasar.

23. Putri Yuriati, Oktia Woro Kasmini Handayani, Eunike Raffy Rustiana, 2016. Evaluasi Pelaksanaan Kegiatan Prevention of mother to child transmission (PMTCT) pada ibu hamil di Kota Tanjung Pinang. Public Health Perspective Journal I. Tanjung Pinang. 
24. R.I. Undang-Undang No.36, 2009 Tentang Kesehatan

25. R.I. Undang-Undang, No.36, 2014 Tentang Tenaga Kesehatan

26. Romdiyah, Nazilla Nugraheni, 2017. Analisis Perilaku Pencegahan Penularan HIV /AIDS pada Ibu Hamil di Puskesmas Kalikajar Wonosobo, Jurnal IImiah Kebidanan, Wonosobo.

27. Siti Ni'amah, Yuli Irnawati, 2017. Studi Deskriftif pengetahuan Ibu Hamil tentang HIV/AIDS dan VCT dengan kesediaan mengikuti VCT di Kabupaten Pati, ISSN 2407-9189. The 6th University Research Colloquium. Pati.

28. Sutanto Priyo Hastono, 2017. Analisis Data Pada Bidang Kesehatan, Ed 1, Cet 2, Depok, Rajawali Pers, 2017

29. Tadesse Fikre Lem, 2014. Assesment of Antenatal Care Clients' Willingness for HIV Councelling and Testing in Asella Govermental Health Institutions, Ethiopia. Universitas Sains \& Teknologi Adama Sekolah IImu Kesehatan Asella, Ethiopia.
30. Tyan Ferdiana Hikmah, Dwi Novitasari, Umi Aniroh, 2015. Faktor-Faktor Yang Mempengaruhi Ibu Hamil Untuk Melakukan Screening Hiv/Aids Melalui Program Prevention of Mother To Child Transmission (Pmtct) Di Wilayah Kerja Puskesmas Kretek Bantul Yogyakarta, Yogyakarta.

31. Yohannes Ejigu, Biniyam Tadesse ,William A. Paxton, 2016. HIV testing during pregnancy for prevention of mother to child transmission of HIV in Ethiopia. Ethiopia.

32. Yunida Halim, Syamsulhuda BM, Aditya Kusumawati, 2016. Faktor faktor yang berhubungan dengan perilaku Ibu Hamil dalam pemeriksaan HIV di Wilayah Kerja Puskesmas Halmahera Kota Semarang, Jurnal Kesmas. Semarang. 
Jurnal Untuk Masyarakat Sehat (JUKMAS) 